\title{
The Evolution of the Study of Executive-Legislative Relations in Latin America: Or How Theory Slowly Catches Up with Reality
}

\author{
Miguel Carreras | PhD Candidate | Department of Political Science University of \\ Pittsburgh | www.miguelcarreras.com
}

\begin{abstract}
The last twenty years have witnessed an explosion in the number of books and articles that focus on executive-legislative relations in Latin America. Since the publication of the seminal Linz article on the "perils of presidentialism" (1990), we have learnt a lot about the interaction between the executive and the legislative branch of government. This review article attempts to make sense of the evolution of the study of executivelegislative relations, by focusing on the inconsistencies between the mainstream theoretical approaches and the reality of executive-legislative relations in the region. Three major changes in the study of executive-legislative relations (unpacking of the "black box" of presidentialism, study of presidential coalitions, and analysis of impeachment processes) are discussed.
\end{abstract}

\section{Introduction}

The relation between the president and the legislature is probably the most studied topic in Latin American politics. The Third Wave of democratization almost immediately generated numerous studies on executive-legislative relations. The main focus of this first wave of studies on executive-legislative interactions in Latin America was to analyze the impact of the relations between the president and the legislature on governability and democratic stability in the region. Many of these foundational works saw the risk of executive-legislative conflict as one of the main perils of presidentialism, as compared to the stability and the efficiency associated with parliamentary systems (Linz, 1990). In this essay, I will take as a point of departure these early institutional analyses, and then evaluate the evolution in the study of executive-legislative relations in Latin America in the last two decades.

This article will proceed as follows. First, I present the "perils of presidentialism" approach and the first response of scholars of political institutions as captured mainly by the classic book Presidents and Assemblies (Shugart \& Carey, 1992). Second, I present the consistencies in the last two decades by showing that many of the original research questions remain central in the study of executive-legislative interactions. Third, I present some of the inconsistencies in the literature by focusing on the new theoretical approaches developed in the last ten years: the study of presidential coalitions and the study of interrupted presidencies. I conclude by considering whether these new research trends are related to a pattern of political change or to new interpretations of similar patterns.

\section{Executive-Legislative Relations and the Perils of Presidentialism}

The first wave of studies of political institutions after the beginning of the Third Wave was marked by the comparison between presidential and parliamentary systems by many prominent scholars. 
The democratization of many countries in different regions in a short time span generated a series of timely research questions regarding the likelihood of efficient governability and democratic stability (and consolidation) under presidentialism and under parliamentarism. Many articles and books were published comparing these two systems. Titles such as Parliamentary Versus Presidential Government (Lijphart, 1992b) are characteristic of that period in the early 1990s.

According to this first wave of research, executive-legislative relations in presidential systems were prone to conflict. The separation of power was presented as a liability of presidential systems that threatened the consolidation of democratic regimes in Latin America. Executive-legislative relations were presented as more conflictive in presidential systems for four main reasons. First, presidential systems permit dual democratic legitimacy. Both the president and the legislators in congress are popularly elected. According to this perspective, a disagreement between the executive and the legislative branch almost inevitably leads to a situation of deadlock. In the words of Lijphart (1992a: 15), the problem of executive-legislative conflict "is the inevitable result of the co-existence of the two independent organs that presidential government creates and that may be in disagreement." Second, the problem of executive-legislative conflict is aggravated by the temporal rigidity of presidential systems. The fixed term in office of the president and the fixed duration of the legislative period do not leave room for the readjustments that political events may require. In a parliamentary system, the prime minister can be changed at any time without creating a regime crisis. In presidential systems, the fixed term in office of the president increases the likelihood of deadlock, governability crises, and regime breakdown (Linz, 1990, 1994). Third, presidential elections generate a "zero-sum" or a "winner-takes-all" result. Whereas in parliamentary systems many parties may form broad coalitions after the election, presidential elections lead to outcomes in which one party wins and everybody else loses. The concentration of power in the executive gives the president little incentive to form coalitions (Lijphart, 1992a: 19). Finally, presidential systems produce a more conflict-prone political style in the part of the executive. In the words of Linz (1994: 19), "the feeling of having independent power, a mandate from the people (...) is likely to give a president a sense of power and mission that might be out of proportion to the limited plurality that elected him." This in turn can produce tensions between the presidents and the legislators of non-incumbent parties (see also 0’Donnell, 1994).

This pessimistic view of the link between presidentialism, executive-legislative conflict, and regime crisis was rapidly tested in the early 1990s in a series of works by Stepan and Skach (1993, 1994). These scholars compare the democratic stability of countries that gained independence between 1945 and 1979. They found that countries that started independence as parliamentary systems were more likely to become or remain democracies than countries that started as presidential systems.

The title of a book edited by Linz and Valenzuela (The Failure of Presidential Democracy) captures well the mood of the scholarly community in the early 1990s. Presidentialism and stable and functioning democracies were seen as incompatible. The book Presidents and Assemblies (Shugart \& Carey, 1992) represented a major break with the conventional wisdom. One of the arguments of this book is to show that all the criticisms leveled at presidential systems were exaggerated, and overlooked some important advantages of presidentialism - accountability, identifiability, mutual checks - (Shugart \& Carey, 1992: chapter 3). However, the most important contribution of this book was an innovative approach that moved away from the presidentialism vs. parliamentarism research design. According to the authors, presidential systems are not all alike. Different presidential systems have different institutional arrangements (presidential powers, party systems, electoral systems, electoral cycles), each of which has implications for democratic stability, governability, representativeness, and accountability. Moreover, they introduce the idea of trade-offs between different institutional characteristics. Some institutional arrangements (e.g., a multiparty system) may favor representativeness while posing an obstacle to governability. In sum, the authors assess the strengths and weaknesses of various forms of presidential systems. They also evaluate how these institutional characteristics influence the prospects for cooperation between presidents and assemblies. For instance, in chapter 8 the authors evaluate the legislative and non-legislative powers of presidents. ${ }^{1}$ They conclude that "relatively strong assemblies should be associated with stable and effective government relative to strong presidencies" (Shugart \& Carey, 1992: 165). Interestingly, the authors also argue that some of the powers held by the president may be delegated by the assembly. Another example comes from the discussion of the electoral cycle in chapter 11 . Shugart and Carey argue that the likelihood of harmonious relations between the executive and the legislature decreases when the elections are held non-concurrently.

In sum, Shugart and Carey adopted an innovative approach by looking at the institutional characteristics of different presidential systems, rather than assuming that all presidential systems were similar. This approach paved the way for a new generation of studies on executive-legislative relations. In their pathbreaking contribution, however, Shugart and Carey did not address two important institutional dimensions that would be analyzed in future research: coalition formation and impeachment procedures. The next two sections focus on the evolution of the study of executive-legislative relations in Latin American from the publication of Presidents and Assemblies onwards. 


\section{Continuities in the Study of Executive- Legislative Relations in Latin America}

Many of the research questions addressed by the seminal works reviewed in the previous section have remained central in the study of executive-presidential relations in Latin America in the past 15 years.

The interest on survival of presidential democracies has gradually declined and been replaced by more timely issues given the decrease in the rate of breakdowns after the Third Wave of democratization (Mainwaring \& Pérez-Liñán, 2005). However, some studies in this area exist. These studies cast serious doubts on the arguments and findings of the "perils of presidentialism" literature in the early 1990s. Shugart and Mainwaring (1997) argue that the correlation between parliamentarism and democracy presented in the work of Stepan and Skach (1994) is doubtful because they do not control for key factors, such as income level, population size, and British colonial heritage. They show that presidentialism is more likely to be adopted in Africa and Latin Ameri$\mathrm{ca}$, regions that tend to be unstable for reasons that are largely unrelated to the form of government. Although the evidence is not conclusive either, it seems from their data that the link between regime type and democracy has been greatly exaggerated. However, the link still exists according to a more recent statistical analysis conducted by Cheibub (2002). Although Cheibub finds that presidential regimes are more unstable than parliamentary regimes, he also demonstrates that the causal mechanism put forward by Linz (1990) and Lijphart (1992a) is not valid. Using data from all presidential democracies that existed between 1946 and 1996, Cheibub shows that minority governments and executive-legislative deadlock do not affect the survival of presidential democracies. Shugart and Mainwaring (1997), and Cheibub (2002) continued to address a research question that was introduced by the "perils of presidentialism" literature in the early 1990s. However, their main findings were inconsistent with the arguments advanced by Lijphart and Linz.

Most of the recent contributions to the literature take Presidents and Assemblies (rather than Linz) as their point of departure. Numerous books and articles have expanded, amended, and proposed important revisions to the model advanced by Shugart and Carey in their classic book. Presidents and Assemblies provided a comprehensive model of executive-legislative relations in Latin America. However, many aspects of the model remained untested (or weakly tested) in the book. A new generation of scholars in the last fifteen years has studied different aspects of the broad framework proposed by Shugart and Carey (1992). I cannot do justice to this blossoming literature in a few pages, but in the remainder of this section, I present some important examples of this research tradition that compares executive-legislative relations in different presidential systems by focusing on certain institutional characteristics.
Mainwaring and Shugart study the link between the party system and executive legislative relations (Mainwaring, 1993; Mainwaring \& Shugart, 1997). These scholars argue that presidential systems and multipartism are a "difficult combination" which is inimical to stable democratic governance for three main reasons. First, the risk of executive-legislative deadlock is more acute because the president is likely to lack stable support in the legislature in a fragmented system with many relevant parties. Second, in multiparty systems, competition tends to be centrifugal which makes compromise and cooperation between the different parties (and between the different branches of government) more difficult to achieve. Finally, the formation of interparty coalitions to deal with these problems is difficult in presidential systems.

Other scholars focus on the link between the legislative powers of the presidents and executive-legislative relations. The legislative powers of the president can be defined as "those legislative powers granted to the president or the executive branch in the constitution. The faculties normally deemed most important in presidential systems are decree power, veto power, and the exclusive power of legislative introduction" (Jones, 2002: 182). ${ }^{2}$

A series of scholars focus on decree powers and investigate why decree authority is widely used in certain presidential systems and not in others. Carey and Shugart (1998) argue that the usurpation interpretation has been overstated. Decree authority tends to be delegated by the legislative assembly, either by statute or in the negotiation that leads to a new constitution. But the legislature maintains a series of powers (e.g., easy overrule of the decree) that keeps this delegated power in check. The delegation of decree power is used to break policy impasses. Hence, the use of decree powers should not be equated with strong presidents acting beyond the constitutional limits on their offices. On the contrary, decree powers are more likely to exist in presidential systems where the distribution of power between the president and the legislature is relatively even. Pereira et al. (2005) qualify these findings. Using data on decree use by four Brazilian presidents between 1988 and 1998, they find inconsistent support for both theories (usurpation theory and delegation theory). Collor de Mello used decrees unilaterally to bypass an uncooperative legislature, while Cardoso made use of a decree power delegated by a supportive congress. Hence, this study argues that there is not a "one-size-fits-all" theory of decree use in presidential systems. The political context is then key for understanding when decree authority will be delegated and when it will be usurped by the executive.

Alemán and Schwartz (2006) use a series of game theoretic models to analyze presidential vetoes in Latin American countries. This article locates itself clearly within the framework proposed by Presidents and Assemblies. Alemán and Schwartz argue 
that the presidential veto does not necessarily lead to executive-legislative deadlock. There are many clauses that cover the veto in the constitution (e.g., re-drafting procedures) that increase the likelihood of a compromise between the two branches of government. They conclude that it is a mistake to think that presidential systems (and more specifically presidential vetoes) automatically lead to executive-legislative conflict.

Finally, some studies have focused on the impact of the electoral cycle on legislative fragmentation, which is in turn associated with governability and democratic stability. Carey and Shugart (1995) show that the share of seats obtained by the president's party tends to decline when elections are held later in a president's term. Hence, when presidential and legislative elections are staggered, the likelihood of an opposition majority in congress significantly increases. In a more recent study, Golder (2006) analyzes the impact of presidential elections on legislative fragmentation. Using a dataset that covers all democratic legislative and presidential elections between 1946 and 2000, he finds that the impact of presidential coattails on legislative fragmentation is contingent on the number of presidential candidates. He concludes that the adoption of runoffs by newly democratic presidential regimes may produce governability problems, creating more fragmented legislatures.

In sum, many of the contributions in the literature on executive-legislative relations in the last fifteen years follow Presidents and Assemblies and qualify even further the arguments made by Linz and others in the early 1990s. Not all presidential systems are prone to conflict between the executive and the legislature, and even the institutions that seem more problematic for democratic governability and regime stability (e.g., presidential vetoes, decree powers) appear to be harmless in most circumstances.

\section{New Dimensions in the Study of Executive-Legislative Relations}

\section{The Study of Presidential Coalitions}

The study of presidential coalitions was neglected by students of executive-legislative relations in Latin America until recently. As previously mentioned, the "perils of presidentialism" literature presented presidentialism as a system in which the winner takes all. Despite its many important contributions, Presidents and Assemblies also ignored this fundamental issue. Political scientists appeared to believe Linz' argument about the impossibility of forming coalitions in presidential systems at face value. The publication of an article in 2004 completely debunked this myth (Cheibub, Przeworski, \& Saiegh, 2004). This article provides data showing that coalition formation is almost as likely in presidential systems as in parliamentary systems. Government coalitions occur in more than one-half of the situa- tions in which the president's party has a legislative minority (Cheibub et al., 2004). In the last ten years, the study of presidential coalitions has increased exponentially. Three dissertations (unfortunately unpublished) have recently been written on the subject (Deheza, 1997; Martinez-Gallardo, 2005; Zelaznik, 2001), as well as many articles.

The first focus of this new line of inquiry has been to investigate whether presidential coalitions improve the conditions for governability in presidential systems. Using data on executive-legislative conflicts and on interrupted presidencies in Latin America during the period 1978-2003, Negretto (2006) analyzes the different factors that are related to governability crises in Latin America. He argues that looking at the size of the president's party is insufficient because the president may create coalitions by inviting members of other parties to join the cabinet. His empirical analysis demonstrates that the likelihood of executive-legislative conflict decreases considerably when a cabinet coalition holding a majority of legislative seats is formed. Cheibub et al. (2004) study the impact of coalition formation on democratic survival with a bigger dataset (including data from almost all democracies that existed between 1946 and 1999). They find that coalition status has no effect on democratic stability. Combining the findings of these two studies leads to a preliminary conclusion: minority governments in presidential systems that do not form cabinet coalitions are more likely to face executive-legislative conflicts than majority governments, but are not more likely to suffer a democratic breakdown.

Another line of inquiry looks at the effects of coalition formation on policy-making. For instance, Amorim Neto (2006) proposes a decision-theoretic approach to policy-making in Latin America. He argues that presidents have two possible policy-making strategies: 1) a strategy based on executive imposition, and 2) a strategy based on the use of statutes. He then demonstrates empirically that presidents that favor a statutory strategy are more likely to form a cabinet coalition. Amorim Neto \& Borsani (2004) show in a more direct way the impact of cabinet coalition on policy-making. Their work identifies the political determinants of the level of public spending and the primary balance of ten democratic regimes in Latin America between 1980 and 1998. The most relevant for this discussion is that they find that presidents backed by cabinet coalitions are more likely to reduce public spending and generate fiscal equilibrium.

\section{The Study of Interrupted Presidencies}

The possibility of removing the president before the end of his or her term appeared remote to the scholars emphasizing the perils of presidentialism in the early 1990s. In the words of Linz (1994: 8), presidentialism leads to a political process that "becomes broken into 
discontinuous, rigidly determined periods, without the possibility of continuous readjustments as political, social, and economic events might require." The book Presidents and Assemblies also pays little attention to impeachment procedures and other processes that can lead to an interrupted presidency. This is also a line of inquiry that has greatly expanded in the last five years.

All scholars working on this issue attempt to identify the determinants of presidential breakdown (without democratic breakdown). The formal process of impeachment is just one of the possible ways in which the interruption of the president's term in office can occur. For instance, de la Rúa in Argentina in 2001 and Sánchez de Lozada in Bolivia in 2003 resigned after popular protests without a formal process of impeachment. These different processes that lead to the fall of democratically elected presidents can all be captured in the generic term "interrupted presidency". The literature has identified a series of factors that increase the likelihood of interrupted presidency.

First, there are a series of institutional factors. Kim and Bahry (2008) examine the sources of presidential interruptions in new democracies from 1974 through 2003. Their statistical analysis demonstrates that divided government and party fragmentation increase the likelihood of presidential fall. Minority presidents appear to be more exposed to face a crisis that could lead to an early termination of their term in office. Pérez-Liñán (2007: chapter 6) offers a more fine-grained theory based on qualitative information on six cases of attempted impeachment in Latin America between 1992 and 2003. According to this author, the size of the president's party in the legislature is only part of the story. The strategy adopted by presidents in their interactions with congress early on in their term may create the conditions for a presidential interruption or, on the contrary, create a "legislative shield" to protect the presidents from impeachment later on. Pérez-Liñán shows that presidents that chose a strategy of "isolation" or "confrontation" when their terms started could not survive impeachment processes. On the other hand, presidents that adopted a policy of negotiation with congress were able to survive the impeachment crisis.

The most important of the non-institutional factors is probably popular outrage. Public disenchantment results from deep economic crises and political scandals involving the president (Pérez-Liñán, 2007: chapter 5). Deep public dissatisfaction may result in popular uprisings against the president. Analyzing elected presidents in Latin America between 1978 and 2003, Hochstetler (2006) argues that street protests are the main determinant of presidential fall. Pérez-Liñán (2007: chapter 4) discusses the role of the media in communicating scandals that increase popular dissatisfaction with democratic presidents. The liberalization that followed the Third Wave of democratization increased the freedom of the press and permitted the creation of a right environment for the politics of scandal.

Whatever the reasons of this phenomenon, the increase in the number of interrupted presidencies may be redefining the nature of executive-legislative relations. If the congress uses the impeachment process more often, the balance of power between the executive and the legislative branches of government may be shifting. Some scholars argue that recent trends represent a "de facto flexibilization and/or parliamentarization of Latin American regimes" (Marsteintredet \& Berntzen, 2008). It is probably too early to tell, but the increase in the number of interrupted presidencies represents another blow to the overly schematic view of presidential systems presented by Linz in the early 1990s.

\section{Concluding Remarks}

In this essay, I have identified three main changes in the literature on executive-legislative relations in the last twenty years. The first change was the unpacking of the black box of presidentialism in the seminal book Presidents and Assemblies. This book identified a series of institutional characteristics that differentiated presidential systems, and rejected the parliamentarism vs. presidentialism research design. The second change was the emergence of a group of scholars interested in cabinet coalitions in presidential systems. The last and most recent change is the emergence of a new line of inquiry that focuses on interrupted presidencies. These changes resulted from inconsistencies between the prevailing theories and the observed realities of Latin American politics.

But to what degree do the changes in the literature reflect changes in actual patterns of politics-and to what degree do they reflect new interpretations of similar patterns?

In the case of the first two changes (unpacking of the black box of presidentialism, and study of presidential coalitions), it seems fairly clear that the changes in the literature represent new interpretation of similar patterns. Presidents and Assemblies was published in 1992 only two years after the publication of the classic article by Linz on the "perils of presidentialism". Shugart and Carey propose to look at a series of institutional characteristics to differentiate presidential systems, such as the legislative powers of the president, electoral rules, electoral cycles, and party systems. All these institutional arrangements already existed when Linz wrote his article. Hence, Shugart and Carey challenged the conventional wisdom by proposing a re-interpretation of the same patterns that Linz studied.

Similarly, presidential coalitions did not emerge in the late 1990s when scholars suddenly became interested in the topic. Studies by Cheibub et al. (2004) and Negretto (2006: 76-77) clearly show that presi- 
dential coalitions already existed in the 1980s and 1990s. However, scholars interested in executive-legislative relations in Latin America seemed to accept at face value the argument made by Linz that the winner takes all in presidential systems. For instance, Mainwaring (1993: 200) identifies three difficulties presidents have in forming coalitions in presidential systems: “First (...), in presidential systems, presidents put together their own cabinets, and the parties are less firmly committed to supporting the government. Second, in contrast to the situation in parliamentary systems, in many presidential systems legislators of parties with cabinet portfolios do not support the government. Third, incentives for parties to break coalitions are generally stronger in presidential systems." Recent developments in the literature of executive-legislative relations have challenged this conventional wisdom by showing that presidential coalitions can be formed and remain stable, and that they have a considerable impact on executive-legislative relations.
On the contrary, the most recent change in the literature (i.e., the study of the causes of presidential falls) is not a re-interpretation of an unchanging reality, but rather an effort by a group of political scientists to catch up with an emerging trend in Latin American politics. As pointed out by Mainwaring and Pérez-Liñán (2005), the rate of democratic breakdown has decreased considerably since the Third Wave. However, severe political crises still exist. In some cases, the resolution of these crises involves a presidential fall, which is provoked by an unsopportive congress or a popular uprising (or a combination of both). Table 1 in Marsteintredet and Berntzen (2008) clearly shows that the number of interrupted presidencies has greatly increased in the last fifteen years. In this case, then, it seems that political science is catching up with a new reality, rather than re-interepreting an existing reality.

\section{References}

Alemán, E., \& Calvo, E. (2010). Unified Government, Bill Approval, and the Legislative Weight of the President. Comparative Political Studies, 43(4), 511-534.

Alemán, E., \& Schwartz, T. (2006). Presidential Vetoes in Latin American Constitutions. Journal of Theoretical Politics, 18(1), 98-120.

Amorim Neto, 0. (2006). The Presidential Calculus: Executive Policy Making and Cabinet Formation in the Americas. Comparative Political Studies, 39(4), 415-440.

Amorim Neto, 0., \& Borsani, H. (2004). Presidents and Cabinets: the Political Determinants of Fiscal Behavior in Latin America. Studies in Comparative International Development (SCID), 39(1), 3-27.

Carey, J. M., \& Shugart, M. S. (1995). The Electoral Cycle and Institutional Sources of Divided Presidential Government. American Political Science Review, 89(2), 327-343.

Carey, J. M., \& Shugart, M. S. (1998). Executive Decree Authority. New York: Cambridge University Press.

Cheibub, J. A. (2002). Minority Governments, Deadlock Situations, and the Survival of Presidential Democracies. Comparative Political Studies, 35(3), 284-312.

Cheibub, J. A., Przeworski, A., \& Saiegh, S. (2004). Government Coalitions and Legislative Success Under Presidentialism and Parliamentarism. British Journal of Political Science, 34(4), 565-587.

Deheza, G. I. (1997). Gobiernos de Coalición en el Sistema Presidencial: América del Sur. European University Institute, Florence.

Golder, M. (2006). Presidential Coattails and Legislative Fragmentation. American Journal of Political Science, $50(1), 34-48$.

Hochstetler, K. (2006). Rethinking Presidentialism: Challenges and Presidential Falls in South America. Comparative Politics, 38(4), 401-418.

Jones, M. P. (2002). Legislator Behavior and Executive-Legislative Relations in Latin America. Latin American Research Review, 37(3), 176-188.

Kim, Y. H., \& Bahry, D. (2008). Interrupted Presidencies in Third Wave Democracies. Journal of Politics, 70(3), 807-822.

Lijphart, A. (1992a). Introduction. In Parliamentary versus Presidential Government. New York: Oxford University Press.

Lijphart, A. (1992b). Parliamentary versus Presidential Government. New York: Oxford University Press.

Linz, J. J. (1990). The Perils of Presidentialism. Journal of Democracy, 1(1), 51-69.

Linz, J. J. (1994). Presidential or Parliamentary Democracy: Does it Make a Difference? In J. J. Linz \& A. Valenzuela (Eds.), The Failure of Presidential Democracy. Baltimore: Johns Hopkins University Press.

Mainwaring, S. P. (1993). Presidentialism, Multipartism, and Democracy. Comparative Political Studies, 26(2), 198-228.

Mainwaring, S. P., \& Pérez-Liñán, A. (2005). Latin American Democratization since 1978: Democratic Transitions, Breakdowns, and Erosions. In F. Hagopian \& S. P. Mainwaring (Eds.), The Third Wave of Democratization in Latin America: Advances and Setbacks. New York: Cambridge University Press.

Mainwaring, S. P., \& Shugart, M. S. (1997). Conclusion: Presidentialism and the Party System. In S. Mainwaring \& M. S. Shugart (Eds.), Presidentialism and Democracy in Latin America. New York: Cambridge University Press. 
Marsteintredet, L., \& Berntzen, E. (2008). Reducing the Perils of Presidentialism in Latin America through Presidential Interruptions. Comparative Politics, 41(1), 83-101.

Martinez-Gallardo, C. (2005). Designing Cabinets: Presidents, Politics and Policymaking in Latin America. Columbia University, New York.

Negretto, G. L. (2006). Minority Presidents and Democratic Performance in Latin America. Latin American Politics and Society, 48(3), 63-92.

0'Donnell, G. (1994). Delegative Democracy. Journal of Democracy, 5(1), 55-69.

Pereira, C., Power, T. J., \& Rennó, L. (2005). Under What Conditions Do Presidents Resort to Decree Power? Theory and Evidence from the Brazilian Case. Journal of Politics, 67(1), 178-200.

Pérez-Liñán, A. (2007). Presidential Impeachment and the New Political Instability in Latin America. New York: Cambridge University Press.

Shugart, M. S., \& Carey, J. M. (1992). Presidents and Assemblies: Constitutional Design and Electoral Dynamics. Cambridge: Cambridge University Press.

Shugart, M. S., \& Mainwaring, S. P. (1997). Presidentialism and Democracy in Latin America: Rethinking the Terms of the Debate. In S. Mainwaring \& M. S. Shugart (Eds.), Presidentialism and Democracy in Latin America. New York: Cambridge University Press.

Stepan, A., \& Skach, C. (1993). Constitutional Frameworks and Democratic Consolidation: Parliamentarianism Versus Presidentialism. World Politics, 46(1), 1-22.

Stepan, A., \& Skach, C. (1994). Presidentialism and Parliamentarism in Comparative Perspective. In J. J. Linz \& A. Valenzuela (Eds.), The Failure of Presidential Democracy. Baltimore: Johns Hopkins University Press.

Zelaznik, J. (2001). The Building of Coalitions in the Presidential Systems of Latin America: An Inquiry Into The Political Conditions of Governability. University of Essex, Essex.

\section{Notas}

1 Legislative powers include veto powers, decree powers, agenda setting, budgetary powers, and proposal of referenda. Non-legislative powers include cabinet formation, cabinet dismissal, censure, and dissolution of the assembly.

2 This is not the only way to measure presidential power. Alemán and Calvo (2010) propose a new approach to measuring the legislative weight of the president and Congress based on the approval of each actor's legislative agenda. However, it remains to be seen whether this measure will be adopted by other scholars studying executive-legislative relations in the region. It is not a useful measure if we want to assess the impact of presidential power on legislative success (because presidential power is operationalized with a measure of presidential success). 